\title{
Botanical Control of Late Blight of Potato
}

\author{
B.L. Maharjan ${ }^{1}$, K. Shrestha ${ }^{2}$ and S. Basnyat ${ }^{1}$ \\ ${ }^{1}$ Central Department of Microbiology, Tribhuvan University, Kirtipur, Kathmandu \\ ${ }^{2}$ Nepal Academy of Science and Technology, Khumaltar, Lalitpur \\ e-mail:utpalbodhi@yahoo.com
}

\begin{abstract}
Late blight caused by Phytophthora infestans (Mont.) De Bary is one of the most devastating diseases of potato. Although a large number of synthetic fungicides have been recommended to control this organism, most of them have proved to be pollutive, carcinogenic and the pathogen develops resistance quickly. Botanical control is one of the safe substitutes to be explored to control this phytopathogen. In the present study an attempt has been made to evaluate the antifungal activity of plant extracts against the above pathogen. Crude ethanolic extracts of five different plant materials viz. Brassica nigra, Cinnamomum camphora, Eupatorium adenophorum, Lantana camara and Melia azedarach were screened and tested against the fungal isolate of $P$. infestans. The antifungal activity of the crude extracts was evaluated by agar well diffusion method and two fold broth dilution method. The moisture content was highest in the twigs of L. camara and lowest in the cake of B. nigra. C. camphora gave the highest yield of $70 \%$ while $M$. azedarach had the lowest yield of (9.75\%) of crude extracts. B. nigra was found most effective against $P$. infestans with both MIC and MFC values at $6.25 \mathrm{mg} / \mathrm{ml}$ while $C$. camphora was found least effective. Different types of plant extracts with different concentrations significantly $(\mathrm{P}<0.05)$ inhibited the growth of the pathogen. The extracts used in this experiment were found to be suitable for the control of the pathogen.
\end{abstract}

Key words: botanical control, antifungal, MIC, ZOI, MFC

\section{Introduction}

Potato (Solanum tuberosum) is one of the world's most nutritious tuber crops that can meet the food needs of people in a substantial manner (Chadha \& Grewal 1993). It occupies the fifth position in area coverage and second in total production and first in productivity among the food crops grown in Nepal. Late blight, a devastating disease, caused by $P$. infestans (Mont.) De Bary, is the most important biotic constraint of potato production in the world claiming the complete destruction of the crop. The disease is prevalent wherever the potato is grown. In high hills late blight occurs every year with the significant yield loss whereas, in Terai the disease epidemic usually occurs after 2-3 years causing substantial yield losses (NPRP 2006). The application of protective chemical fungicides prior to the infection has been one of the common practices against the disease outbreak. The problems associated with the use of hazardous chemicals for plant disease control has received increasing attention worldwide because it causes health hazards, environmental pollution, pathogens become resistant to chemical pesticides and ecological imbalances may occur (Fry 1982). In recent years, there has been a growing movement in the world to reduce the amount of synthetic pesticides being applied to the environment. According to a study, only one percent of the total pesticide applied has become effective in controlling pests, remaining 99\% goes into various environmental systems (Dhaliwal \& Arora 2001). Botanical control is an alternative to chemical control that deserves elaborative research.

Botanical extracts have been reported to be effective against the diseases of many crops. According to Wang et al. (2004) Inula viscosa leaf paste either dissolved in acetone or emulsified in water effectively controlledlate blight of potato or tomato. Ghorbani et 
al. (2005) observed that the antagonistic microorganisms and the different compost tea extracts showed the variation in the reduction of the blight disease with 10 to $50 \%$ and 30 to $40 \%$ respectively compared to control plants. Khair and Wafaa (2007) observed the most reduction in late blight disease severity while using lemon grass leaves and chilli fruit extracts. Doughari and Obidah (2008) demonstrated the highest activity from acetone extracts of Leptadenia lancifolia against $P$. infestans.

Most of the Nepalese plants possess one or more of the chemical properties such as antimicrobial, antifungal, antiviral, antihelmintic, anticancer, sedative, laxative, cardiotonic and diuretic. Different parts of plants can be successfully used for controlling various insect pests due to the presence of secondary metabolites (Parajuli et al. 1998). These botanical pesticides are natural products that can even be used in their crude form. They are far low toxic to non-target organisms, biodegradable and environmentally safe (Neupane 2003).

According to Shrestha (2003) Krilaxyl, Dithane M45, neem, mugwort and Trichoderma significantly inhibited the development of mycelium of $P$. infestans isolate from Nepal. Timila (2004) studied the effect of organic amendments on the Phytophthora blight of pepper under screenhouse conditions in which only mustard meal reduced disease incidence significantly. Sharma (2007) reported that the antagonist fungus Trichoderma viridae and extracts of Artemisia indica Willd were little efficient to control late blight but increased the tuber yield significantly by $20.4 \%$. Timila and Ashley (2008) observed the significant reduction in incidence of Phytophthora blight of pepper with application of mustard meal ( $0.5 \%$ amended).

This study was therefore designed to investigate the efficacy of the ethanolic extracts of different plant materials against the $P$. infestans isolated from the infected potato plants.

\section{Methodology}

The experiment was conducted at the Natural Products Research Laboratory of Nepal Academy of Science and Technology (NAST).

\section{Preparation of the plant materials and their extracts}

All the selected fungicidal plant materials, namely Brassica nigra (cake), Cinnamomum camphora (ripened fruits), Eupatorium adenophorum (twigs), Lantana camara (twigs) and Melia azedarach (ripened fruits) were collected from Kirtipur (Kathmandu). The collected plant materials were shade dried and their moisture content was determined. The completely dried plant materials were grinded to powder form using a grinder and kept in air tight containers until their use. For extraction of bioactive components, $100 \mathrm{~g}$ of each powdered materials were subjected to continuous soxhlet extraction using ethanol (100\%) as solvent and the obtained extracts were concentrated under reduced pressure using rotary vacuum evaporator (Tiwari et al. 1992). The crude extracts obtained were kept in bottles, sealed and stored in refrigerator $\left(4^{0} \mathrm{C}\right)$ use. The working solutions of the extracts were prepared in dimethyl sulfoxide (DMSO).

\section{Isolation and Identification of $\boldsymbol{P}$. infestans}

The leaf samples of infected potato plants were collected from the fields of Kathmandu valley. The infected leaf tissues were surface sterilized and placed in antibiotic amended Rye A agar and PDA media. The inoculated media plates were incubated at $18^{\circ} \mathrm{C}$ for 5 days in the dark. The isolated fungal organisms were identified on the basis of cultural characteristics and microscopic observation (Sato \& Kato 1993).

\section{Evaluation of antifungal activity}

The antifungal activity was evaluated by agar well diffusion method as given by Dingle et al. (1953). The method evaluated the antifungal activity of the plant extracts with the determination of zone of inhibition (ZOI). For antifungal assay, the standard inoculum was prepared according to Aberkene et al. (2002). The wells were made in the inoculated media plates with the help of sterile cork borer (diameter $6 \mathrm{~mm}$ ). Fifty microlitres of each working solution of the plant extract of different concentration ( $5 \mathrm{mg} / \mathrm{ml}, 10 \mathrm{mg} / \mathrm{ml}, 30 \mathrm{mg} / \mathrm{ml}, 50 \mathrm{mg} /$ $\mathrm{ml}$ and $100 \mathrm{mg} / \mathrm{ml}$ ) were loaded into the wells. The plates were then left for half an hour so as to facilitate diffusion of the extracts in the media. Then the plates were incubated at $18^{\circ} \mathrm{C}$ for 5 days and were observed for the zone of inhibition which was suggested by the clean area without growth around the well. 
The antifungal tests of the extracts were further carried out by two fold broth dilution method so that the antifungal activity could be interpreted in the form of minimum inhibitory concentration and minimum fungicidal concentration.

A two way ANOVA was used for the statistical analysis of the data obtained in the experiment.

\section{Results and Discussion}

The crude extracts of the plant materials were obtained by soxhlet extraction method using ethanol as solvent. Water, the universal solvent, found to be used by the local farmers was not used in the antifungal tests as it can not dissolve non polar organic compounds and also the removal of water from the solution needs high temperature or complex equipment. In a study carried out by Rabe and Van (1997), the antimicrobial activity was shown higher by the alcoholic fraction rather than aqueous extract. So the ethanol was chosen as solvent for the extraction. The moisture content and yield (\%) of the plant materials has been depicted in Table1.

There was a distinct difference in the yield of extracts from different plant materials. The difference in yield might be due to various factors such as time of extraction, type and part of plant materials used, fineness of powder and extent of dryness, etc.

Table 1. Moisture content and yield (\%) of the plant materials

\begin{tabular}{ll|c|c}
\hline SN & Name of the plants & Moisture content (\%) & $\begin{array}{c}\text { Yield of crude extracts on dry } \\
\text { weight basis (\%) }\end{array}$ \\
\hline 1 & Brassica nigra (cake) & 5.00 & 18.38 \\
2 & Cinnamomum camphora (ripened fruits) & 39.65 & 70.00 \\
3 & Eupatorium adenophorum (twigs) & 65.16 & 32.03 \\
4 & Lantana camara (twigs) & 79.09 & 30.29 \\
5 & Melia azedarach (ripened fruits) & 33.38 & 9.75 \\
\hline
\end{tabular}

$P$. infestans does not grow luxuriantly on some of the usual media used for the cultivation of fungi such as cornmeal, PDA or oatmeal agar. The fungus grows slowly and is easily overgrown by other fungi or bacteria (Ingram \& Williams 1991). Hence the antibiotic amended Rye A agar medium was used for the cultivation of the fungus and was subcultured on PDA media (Sato \& Kato 1993).

Table 2. Antifungal activity of different concentration of plant extracts against $P$. infestans

\begin{tabular}{|c|c|c|c|c|c|c|}
\hline \multirow[t]{2}{*}{ SN } & \multirow[t]{2}{*}{ Name of the plants } & \multicolumn{5}{|c|}{$\begin{array}{l}\text { Zone of inhibition }(\mathrm{mm}) \\
\text { (Diameter of well: } 6 \mathrm{~mm} \text { ) }\end{array}$} \\
\hline & & $5 \mathrm{mg} / \mathrm{ml}$ & $10 \mathrm{mg} / \mathrm{ml}$ & $30 \mathrm{mg} / \mathrm{ml}$ & $50 \mathrm{mg} / \mathrm{ml}$ & $100 \mathrm{mg} / \mathrm{ml}$ \\
\hline 1 & Brassica nigra (cake) & - & 8 & 9 & 11 & 12 \\
\hline 2 & Cinnamomum camphora (ripened fruits) & - & - & 7 & 8 & 9 \\
\hline 3 & Eupatorium adenophorum (twigs) & - & 7 & 8 & 9 & 11 \\
\hline 4 & Lantana camara (twigs) & - & 8 & 8 & 9 & 10 \\
\hline 5 & Melia azedarach (ripened fruits) & - & 7 & 8 & 10 & 11 \\
\hline
\end{tabular}

Note: (-) indicates no ZOI

Table 3. MIC and MFC values of different plant extracts against $P$. infestans

\begin{tabular}{ll|l|l}
\hline $\mathbf{S} \mathbf{N}$ & Name of the plants & MIC (mg/ml) & MFC (mg/ml) \\
\hline 1 & Brassica nigra (cake) & 6.25 & 6.25 \\
2 & Cinnamomum camphora (ripened fruits) & 12.5 & 25 \\
3 & Eupatorium adenophorum (twigs ) & 6.25 & 12.5 \\
4 & Lantana camara (twigs ) & 6.25 & 6.25 \\
5 & Melia azedarach (ripened fruits) & 6.25 & 12.5 \\
\hline
\end{tabular}


Different types of plant extracts with different concentration significantly $(\mathrm{P}=<0.05)$ inhibited the growth of the pathogen.The extracts of $B$. nigra, $E$. adenophorum, L. camara and M. azedarach inhibited the growth of $P$. infestans from $10 \mathrm{mg} / \mathrm{ml}$ concentration, $B$. nigra being the most effective one with both MIC and MFC values $6.25 \mathrm{mg} / \mathrm{ml}$. C. camphora showed the inhibitory activity only from the $30 \mathrm{mg} / \mathrm{ml}$ concentration. Similar results were observed by Timila and Ashley (2008) in which mustard meal significantly reduced the incidence of Phytophthora blight compared to untreated check. Timila (2004) also found that only mustard meal reduced the disease incidence of Phytophthora blight disease of pepper compared to untreated plants.

Since the selected plant materials under this study were effective against $P$. infestans isolated from the diseased potato leaves in the laboratory test, the field trials should be carried out prior to using these extracts for the control of the disease. The extraction of these plant materials with other solvents, purification of the crude extracts and the identification of the bioactive compounds should also be done.

\section{Acknowledgements}

The authors would like to thank Ms. Kamil Prajapati for her help during the entire research period.

\section{References}

Aberkene, A., M. Cuenca-Estrella, A. Gomez-Lopez, E. Petrikkou, E. Mellado, A. Monzon, J.L. RodriguezTudela and Eurofung Network. 2002. Comparative evaluation of two different methods of inoculum preparation for antifungal susceptibility testing of filamentous fungi. Journal of Antimicrobial Chemotherapy 50(5):719-722.

NPRP. 2006 Annual Report. National Potato Research Programme, National Agricultural Research Centre, Lalitpur Nepal.

Chadha K.L. and J.S.Grewal. 1993. Potato research in IndiaHistory, infrastructure and achievements. In: Advances in Horticulture Publisher, 7:1-9.

Dhaliwal, G.S. and R.Arora. 2001. Integrated pest management concepts and approaches. Kalyani Publishers, New Delhi, India. Pp. 66-67.

Dingle, J., Red, W.W. and Solomons, G.L. 1953. The enzymatic degradation of pectin and other polysaccharides, applications of the cup assay method to the estimation of enzyme. Journal of Science, Food and Agriculture 40:149-153.
Doughari, J.H. and Obidah, J.S. 2008. Invitro antifungal activity of stem bark extracts of Leptadenia lancifolia. International Journal of Integrative biology 3(2):111-117.

Fry, W.E. 1982. Principles of plant disease management. Academic Press, New York. 378 Pp.

Ghorbani, R., Wilcockson, S. and Leifert, C. 2005. Alternative treatments for late blight control in organic potato: Antagonistic microorganisms and compost extracts for activity against Phytophthora infestans. Potato Research 48:181-189

Ingram, D.S. and Williams, P.H. 1991. Phytophthora infestans, the cause of late blight of potato. Advances in Plant Pathology. Academic Press Ltd. London.

Khair, A.H. and Wafaa, M.H. 2007. Application of some Egyptian medicinal plant extracts against potato late blight and early blights. Reasearch Journal of Agricultural and Biological Sciences 3(3):166-175.

Neupane, F.P. 2003. Integrated pest management in Nepal. Centre for Environmental and Agricultural Policy Research, Extension Development (CEAPRED), Lalitpur Pp. 77-96.

Parajuli, D.P., Gyanwali, A.R. and Shrestha, B.M. 1998. A manual of the important nontimber forest products in Nepal, Training and Manpower Development in C.F.M., Pokhara.

Rabe and Van, S.J. 1997. Antimicrobial activity of South African plants used for medicinal purposes. Journal of Ethnopharmacology 56(1):81-87.

Sato, N. and Kato, M. 1993. Improvement of the selective medium and method for the isolation of Phytophthora infestans. Annals of Phytopathology Society, Japan 50:568-571.

Sharma, B.P. 2007. Efficacy of biological products against late blight of potato. Nepal Journal of Science and Technology 8:7-11

Shrestha, K.K. 2003. Integrated disease management of tomato late blight disease Phytophthora infestans (Mont.) De Bary. Ph.D thesis. University of Connecticut, USA.

Timila, R.D. and Ashley, R.A. 2008. Environmentally safe approaches for the management of Phytophthora blight disease of pepper. Nepal Journal of Science and Technology 5:57

Timila, R.D. 2004. Phytophthora blight of pepper (Phytophthora capsici Leonian) and its integrated management. Ph.D dissertation. University of Connecticut, USA.

Tiwari, K.S., Malhotra, S.N. and Vishnoi, N.K. 1992. A textbook of organic chemistry. Second edition, Vikas Publishing House Pvt. Ltd. New Delhi, India.

Wang, W.Q., Daniel, B.H. and Cohen, Y. 2004. Control of plant diseases by extracts of Inula viscosa. Journal of Phytopathology 94:1042-1047 